\title{
AGE AND GRAMMAR IN ENGLISH LANGUAGE TEACHING IN THE LOWER GRADES IN PRIMARY PUBLIC SCHOOLS IN BELGRADE
}

\begin{abstract}
This paper aims to find out how grammar is presented, explained and practised with the students aged from seven to eleven in junior classes of public primary schools in Belgrade. The learning theories of Piaget, Vygotsky and Bruner that hold the key in know-how of the learning process can be applied in the foreign language learning and language teaching in the classroom. The paper also explores if teaching and learning grammar to children at school bears similarities to the very theories. Regarding the methodology and practical field research, the author has chosen a descriptive approach and class observation to see how grammar is delivered to the pupils. Since some teachers think that there is no any grammar whatsoever in the first and second classes, there is only one description of such classes. Other teachers tend to pay much attend to explicit grammar explanation in the mother tongue, translate the chunks of language and use the deductive approach. The grammar presentation lacks context and is seen in isolation whereas the only way to explain the meaning is translation. The teaching and learning process are in contrast with language learning theories. To improve learning and teaching, models introducing new language and grammar games can be applied in classroom because they provide the context with the meaning and use of a new grammatical item. Teachers may lead students by questions into discovering rules on their own. However, there are various problems in schools and society that can harm the teacher's role and the education itself.
\end{abstract}

Key words: public primary schools, age, grammar, language theories, language teaching, language learning, lesson descriptions, deductive approach.

\section{Introduction}

It is common to hear parents saying to their children: "In the English class do you only learn songs and play or do you do anything serious?". Most adults and laymen who are not in the teaching profession tend to misbelieve that children learn a foreign language in the same way as grown-ups: they can sit

\footnotetext{
* студент докторских студија на Филолошком факултету Универзитета у Београду irenarradic@gmail.com

** Овај рад представља део мастер рада који је одбрањен на Филолошком факултету 2012. године под менторством доц. др Смиљке Стојановић.
} 
throughout the whole class, pay full attention, be disciplined, use higher cognitive skills in learning, etc. However, it is quite the opposite. According to the language learning theories of Piaget, Vygotsky and Bruner, a child is seen as an active participant exploring his/her environment to solve some problems. Thinking and actions they take lead to acquiring new knowledge and constructing learning. In performing activities a child uses language as a tool, which can be applied in conducting their answers in foreign language. Vygotsky coined the term the zone of proximal development to show that a child can develop above the achieved level and do certain tasks with the help of adults or their peers. The very concept can find its place in the classroom with teachers and pupils. Bruner dubbed the terms of scaffolding, routines and formats to illustrate the relationship between parents and children and how language develops gradually. Scaffolding is the help that parents provide to their children so that children could connect new information with the things that they already know. Routines are developed in storytelling where parents read and repeat the story using comprehensible language so that children could tell the story by themselves. Formats cover the roles of both parents and children in storytelling regardless of the kind of book. All these notions can be used in the classroom where the teacher gives instructions by modified language and children who are familiar with the context and routines can make guesses without hesitation.

All the abovementioned theories will be elaborated on further in the paper. To see if these theories work in practice in the context of grammar the modest research was conducted in two primary schools in Belgrade with three teachers. The author observed the classes and used a descriptive method to give accounts of the classes where grammar had been taught to the pupils from the first to the fourth class of primary school. Following these accounts, some advice, improvements, grammar games and lesson plans will be given by famous experts in successful English teaching and learning. Seeing that grammar is not only learnt/acquired differently by adults and children but also that it is too abstract for pupils, this paper explores the ways how grammar is presented, explained and practised in the junior classes of primary school with the aim of understanding how children acquire grammar and whether that learning is in an accordance with language learning theories. However, teachers usually adhere to the grammar-translation method and somewhat deductive approach, explain grammar rules in mother tongue devoid of context and as a result children fail to comprehend grammar and behave in contrast with the theories in question. Moreover, the scope of the research is small since most teachers believe that there is no grammar whatsoever in the first and second class syllabuses. There findings can partially be explained by a number of reasons such as overcrowded and mixed ability classes, maintaining discipline, comprehensive school syllabus, underpaid and unmotivated teachers, the bad image of teacher and the undermining the importance of education and knowledge in the media. 


\section{Theories on Children's Language Learning}

In her book Teaching Language to Young Learners Lynne Cameroon distinguishes a learning-centred perspective from a learner-centred perspective. The former focuses on the facts and information on the learning process, which is viewed as significant to successful teaching, whereas the latter emphasises the child as the focus of teaching and syllabus which is crucial because this perspective sheds light on how children learn language and is incorporated in the three language learning theories (Piaget, Vygotsky and Bruner) (Cameron, 2001: 1).

Jean Piaget considers children as active learners that deal with problems in interaction with their surroundings. Only though action-taking does the learning process take place. For example, a young child makes an effort to put food from the bowl into the mouth using fingers or a spoon realising how to eat. A newly acquired knowledge, skills, thinking and learning constructed by a child actively have their roots in the action itself. (Cameron, 2001: 2,3).

He introduces two different terms such as assimilation and accommodation. The former indicates both adaptive and thinking process in which a child eats with a spoon single-handedly. However, given a fork to consume food, a youngster attempts to apply successfully assimilated skills and knowledge of spoon-feeding in fork-feeding. A child adapts to the new conditions thus performing new actions and gaining new knowledge (Cameron, 2001: 3).

Piagetian theory is significant to language learning because he thinks that children can learn and think actively. Since children look for purposes and intentions in the environment using knowledge and limited experience to understand human's actions and language, Margaret Donaldson regards children as sense makers. Their comprehension of the world is crucial to gather how children react to activities in the language classroom. Namely, the classroom and its activities give rise to opportunities for their development and actions as language learners (Cameron, 2001: 4,5).

In contrast to Piaget, who neglects the social factor, Lev Vygotsky's theory emphasizes the element of social, i.e. language and people in the child's environmental where a child uses language as a tool to perform given activities (Cameron, 2001: 5). A child talks to himself or herself and that kind of talk is called egocentric speech ${ }^{l}$ which evolves into inner speech ${ }^{2}$ (Vigotski, 1983: 121). This gradual change from thinking aloud to thinking internally is called internalisaton (Cameron, 2001: 7). For example, a child that used to count on his or her fingers counts in his/her mind now. The inner speech plays a hugely important role in the development of thinking and the thought itself is seen as blocked unvoiced speech (Vigotski, 1983: 120, 346). Ideas of egocentric speech and inner speech can be applied in foreign language learning. Children can direct their thoughts just as they can conduct their answers in the foreign language to carry out tasks with the help of mother tongue. (Žiropađa, Miočinović, 2007: 103).

\footnotetext{
${ }^{1}$ According to Piaget, while thinking aloud, a child does not care whether adults are able to understand or follow such speech, therefore it is called egocentric (Žiropađa, Miočinović, 2007: 101, 102).

${ }^{2}$ Inner speech denotes thinking internally.
} 
Vygotsky situates the child in the world of people who help children to fulfil tasks and grasp much more than on their own. For example, if a child is not able to fill the spoon with food, parents assist children by cupping their hand over child's and loading the spoon with food. This achievement falls into the zone of proximal development (ZDP) (Cameron, 2001: 6). The very phrase represents difference between what a child can do to solve a problem singlehandedly (achieved level of development) and what a child can do with the help of an adult or a more advanced peer (potential level of development). Whatever action a child takes with adult's support, he or she will be able to perform it independently (Žiropađa, Miočinović, 2007: 103). According to Vygotsky, intelligence and abilities are measured by little push that child receives from adults in order to complete an action (Cameron, 2001: 6).

The notion of zone of proximal development can be applied in classrooms. In Vygotsky's viewpoint, lessons based on this notion can produce good results. Lessons are composed somewhat above the achieved level of development. The learning process in such circumstances influences both emotional and motivational self-being. Disregarding external motivation in the form of marks and prizes, students undergo a change and enjoy in the very learning process via internal motivation (Žiropađa, Miočinović, 2007: 103).

Bruner finds out in what way parents use language to act as mediators and help-providers in problem-tackling. Only though scaffolding and routines can an adult draw a child closer to the surrounding world. The concept of scaffolding denotes support in the form of talk that the child gets from his or her parents so as to get to grips with certain tasks. Such effective scaffolding can be applied in the language classroom by teachers. The teacher's job is to keep in mind the whole task and its aims because children are not yet capable of due to their short attention span. What children are expected to do is pay attention to some section of the task and use language (Cameron, 2001: 8,9).

Moreover, Bruner coined the terms such as formats and routines that provide necessary conditions for scaffolding and connect things children have already known with the novelty. For example, when parents read stories to children, children grow, the sort of book alters and adults and children swap the roles gradually, but the format stays unchanged. Parents modify their output to help the child understand the plot. Finely tuned language and a lot of repetition enable the child to make guesses. At this point, the child is competent to answer questions concerning the story, finish off the story and even read it out loud. Familiarity and alternation are integrative parts of the routine. Within this routine, children not only can play safe and adhere to familiar language, but they can also be in charge of the language and control it. It is called space for growth, which is similar to Vygotsky's idea of zone of proximal development (Cameron, 2001: 9,10).

The parent-child talk shifts to the teacher-pupil talk which encourages and nurtures gradual language development. For example, any routine such as handing out papers is presented to children in the same manner. The appropriate language is tailored for the students' level and given situation. Given the context and acquaint with the routine, children can guess what is going on around them 
and what will happen next. Each activity can take on a tinge of freshness and novelty when a teacher brings more elaborate and complicated language into the activity at hand. Thus children can grasp the meaning of difficult language which is within the child's space for growth (Cameron, 2001: 10, 11).

\section{The Descriptions of Classes}

Only three classes have been observed because the majority of teachers have stated that grammar is not incorporated in the student's books in the first and second grade. Much emphasis is given to teaching and learning vocabulary and the method labelled as total physical response $e^{3}$. The lack of grammar can be explained in two ways only. First, there is really no trace of grammar in the coursebooks. Second, there is hidden grammar that is not recognized as such.

When it comes to the textbooks for the first and second grades, Happy House 1 and Happy House 2 are full of large pictures, photographs and comicfashion illustrations as visuals to engage and encourage children to talk. Familyrelated topics and topic about everyday life are divided into units whereas key vocabulary and grammar points are listed on the contents page. There are simple instructions such as listen to the story, act out the story, listen and point, etc. Seeing that children's exposure to audial stimuli is of crucial importance in this period, key words, questions and sentences can be heard in the songs with a lot of repetition of two or more patterns, dialogues or role-plays. At the end of each unit, most words are revised through songs and children do paper and scissors work in accordance with the topic (bodily-kinaesthetic intelligence $e^{4}$ ).

As for the vocabulary, every topic is followed by key words such as toys, animals, bathroom items, etc. Regarding grammar, there are wh-questions such as what's this?, where's my T-shirt?, how old are you?, yes-no questions expressed in the present simple tense such as is it a balloon? do you like dogs?, numbers and construction I've got. However, sometimes there is a fine line between grammar and vocabulary. For example, imperatives given in the textbook such as clap! stamp your feet! take off your shoes! can be seen as vocabulary items because each word carries a lexical meaning, but these exclamations also belong to the field of grammar because their forms express meaning in terms of instructions and commands (Batstone, 1994: 11). It is possible that interdependent relationship (Batstone, 1994: 8) between grammar and vocabulary lies at the heart of the problem why teachers fail to recognize grammar in the lower language classes.

\footnotetext{
${ }^{3}$ This is a method which advocates learning language through action-taking rather than through drills (Harmer, 1991: 36)

${ }^{4}$ This term involves 'muscular coordination, athletic skill, body language, pronouncing a language'. This intelligence embodies 'pronunciation activities, theater, drama, hands-on projects, body language and non-verbal communication' (Gardner, 2006:38,39)
} 


\subsection{The First Lesson: Describing Location (2nd grade)}

The aim of the lesson is describing location within the house using constructions it's upstairs/downstairs and it's on the left/right. When it comes to the teaching process, the teacher prefers the deductive approach ${ }^{5}$ since she writes on the board these constructions and their translations in the Cyrillic letters because pupils have not fully mastered the Latin letters in Serbian. Pupils repeat new pieces of language together with the teacher after the CD-player. Drills are carried out chorally and individually respectively. In question-answer fashion children look at the picture and answer the teacher's questions such as where is the bathroom/living room/kitchen/bedroom? In their answers not only do they use the construction It's upstairs but also they use the prepositional phrase on the left/right. After drills and practice, children are given a task to draw their house with rooms. While pupils are drawing, the teacher is playing songs on the CD-player. On finishing their house, the teacher asks students individually where the bathroom/living room/kitchen/bedroom is.

\subsection{The Second Lesson: The Present Simple of the verb Like (3rd grade)}

The teacher starts the lesson by writing the paradigm of the verb to like in the Present Simple on the board. This way of presentation is known as chalk and talk (Scrivener 1994: 16).

The teacher explains the meaning of the verb to like by translating it as voleti, dopasti se in the context of the social network Facebook where people click on the like button to show their attitude. The rule for the 3 rd person singular is explained in the mother tongue and the suffix $-\mathrm{s}$ in the third person singular is both circled and underlined. However, pupils tend to pay much more attention to the written stimuli such as the box (Harmer, 1991: 63,64). She mentions contracted forms don't and doesn't derived from do not and does not. After teacher's talking time, pupils read out loud the paradigm. While doing exercises in the book, pupils experience some difficulties. Some children fail to write suffix $-\mathrm{s}$ in the 3rd person singular although the paradigm is also given in the student's book.

In the following exercise children are supposed to circle one of two forms (like/likes) and words and expressions (cheese, apple, speaking English, playing volleyball, etc.) in the sentences talking about three characters in the book, their likes and dislikes. Even though the teacher has translated the instructions in Serbian and the model sentence in the book (I like dancing.) is done to show how to complete the exercise, some children fail to understand it. Such exercises with poor learning value based on the form are called virtual tests (Ur, 1988: 15,16). Moreover, some children fail to comprehend the instructions whatsoever by coping the whole sentence from the very beginning i.e. duplicate both the subject and the predicator.

\footnotetext{
${ }^{5}$ This approach is also known as a rule-driven approach and related to the Grammar-Translation method (Harmer, 2007:29).
} 


\subsection{The Third Lesson: Countable and Uncountable Nouns (4th grade)}

At the very beginning of the class, the teacher and students revise orally what they have done in the previous classes - Present Simple and Present Continuous. The explanations on the usage of these tenses are given in Serbian by teacher. For example, Present Simple is used to talk about usual activities whereas Present Continuous is used to talk about temporal actions. The teacher gives examples of the two tenses such as I run every day and I'm running now. After revision, the teacher asks children if they watch TV/eat chocolate/go to school every day. Students answer yes, I do/ no, I don't. What the teacher tries to elicit from students is to make a question out of the sentence I'm running now and the teacher gives the suitable answer to her question No, I am not. Students make questions by inversion am I running now.

Students are to divide all the nouns written on the board into two categories countable and uncountable. The teacher makes sure whether the children have understood the instructions given in English by asking them to translate instructions. Two students go to the board - one writes countable nouns while the other writes uncountable nouns. After checking the answers on the board, the teacher moves on to the next practice. By giving explanation in both English and Serbian, the teacher asks students to choose five nouns and make questions out of them starting with how much/many, e.g. how many apples are there in the fridge? If this proves difficult for students, as it has turned out to be, the teacher simplifies the task by restating the question how many apples have you got in the fridge? Students work individually, raise their hands and read their sentences. After pupils have listened to the text in the book once, they do a role-play (without quantifiers much and many).

In the following paragraphs, lesson plans of the described classes will be elaborated and improved by experts such as Jeremy Harmer, Scott Thornbury and Penny Ur. The very lesson plans are examples of good teaching practice.

\section{Lesson Plans Improved by Experts}

When a teacher presents a new grammatical point Do you like X? Yes I do/No I don't, a gapped dialogue is a good start. After gap-filling and this comprehension task, pupils use a new piece of language to talk about their likes and dislikes. This stage is called personalisation (Harmer,1997: 19). Pupils can fail to concentrate on one single thing for a long time but if immersed in the topic at hand, children can speak language well and easily (Harmer, 2007: 15).

In his other book, Harmer puts forward the idea of a general model for introducing new language be it countable/uncountable nouns be it the verb like. The model consists of five elements: lead-in, elicitation, explanation, accurate reproduction and immediate creativity.

In the first stage the context has to be introduced together with the meaning and use of the new language. Harmer introduces the idea of a key concept that represents the information crucial to understand the context and therefore the meaning and use (Harmer, 1991: 60,61). According to this author, a survey 
on international national dishes between interviewer and interviewee (Harmer, 1996: 20) can provide a good context for meaning and use of the verb like. Key concepts such as survey, interviewer and interviewee are necessary for understanding the context. Beside the context, the teacher should demonstrate the use of a new language (Harmer, 1991: 61). If the survey is used as a context-provider, the interview will only use the same part of speech - nouns, e.g. I like pizza/spaghetti/octopus, etc.

The elicitation stage enables the teacher to choose what stage he or she will take next depending on how well the learners' performance turns out to be. For example unless children are capable of producing a new language whatsoever, the teacher will introduce the explanation stage. If the students know how to produce new piece of grammar with no major mistakes, teacher will opt for the accurate reproduction stage to solve out those difficulties. However, if learners can produce it accurately, the immediate creativity stage will be introduced. The elicitation stage is significant since it provides the teacher with necessary information that will show him or her what step to take next (Harmer, 1991: 61).

In the explanation stage the prime focus is on the form. The teacher can explain the form using the blackboard, listening drill or mother tongue. When explaining statements and questions, the teacher can use explanation techniques (Harmer, 1991: 61). Apropos of statements, models such as she likes chocolate or does she like chocolate? can be elaborated on through the procedure that is divided into steps and goes like this:

Step 1: Using normal stress and intonation, a teacher pronounce the model. This can be carried out more than once.

Step 2: The teacher extracts one word from the sentence and such step is called isolation.

Step 3: The teacher divides the word to demonstrate its elements within the word in question.

Step 4: The teacher repeats again the isolated word.

Step 5: The normal model is presented again.

This is how the procedure works in practise:

T: Listen...She likes chocolate...She likes chocolate...Listen...likes...likes...like.../s/...like

.../s/...likes...she likes chocolate...she likes chocolate.

There is also a technique which is used for beginners called using hands and gestures to explain how a word is contracted in speech. Namely, each finger can stand for each word, e.g. She doesn't like chocolate. By joining an index finger (which represents verb does) with the middle finger (which denotes not), the teacher can show how those two words merge (Harmer, 1991: 62-64).

In the accurate reproduction stage drills play a key role as controlled practices. Children reiterate and practise patterns or models so as to produce a new piece of grammar correctly. The accuracy is placed in the foreground whe- 
reas the meaning and use are in the background (Harmer, 1991: 61). All the drills can be carried out chorally, individually ${ }^{6}$ and by cue-responses. Using cue response drills, the teacher elicits answers from students (Thornbury, 1999: 95). For example:

T: Tea?

S: How much tea have we got?

After oral prompts such as spaghetti, meat, juice, sugar, etc. the teacher repeats the whole process but this time using flash cards as prompts. Now the teacher repeats the sentence by inserting countable nouns in patterns, e.g. How many bananas have we got? The teacher first uses words as cues such as potatoes, eggs, tomatoes, etc. and then pictures as cues. At the end of drilling, the teacher uses prompts that consist of both uncountable and countable nouns. Such type of drill in which students should make a difference between two models and alter patterns is called variable substitution drill. At the end of the class, the teacher hands out pictures to the students so that they could check their knowledge in pair work (Thornbury, 1999: 95, 96).

It is vital to give students feedback such as 'yes', 'yeah', 'good' or any kind of correction so that learners should know whether their answer is correct or not. Calling out students' names randomly can bring excitement in the class and keep them alert. It is strongly recommended that the accurate reproduction stage does not last for more than ten minutes because the interest of children wears off (Harmer, 1991: 62-68).

In the immediate creativity stage students are expected to apply new grammar to make their own sentences, not models. If learners can perform this task, they have grasped the meaning, use and form of the new item (Harmer, 1991: 62).

Here is the plan for presentation of likes and dislikes divided into two phase. Besides the table given in the Harmer's book, the author of this paper has made a new ordering stages of the general model of introducing a new language and described each stage (see the Appendix 6) (Harmer, 1996: 73, 74).

\section{Grammar practice activities (Grammar games)}

Efficient activities should contain three important elements: the task itself, the interest and learner activation. A good language-practice task has two important features: clear goals and active language use. The most successful grammar exercises contain two objectives - language-based and non-linguistic, e.x. to find solutions to some problem, ask yes-no questions to guess what the teacher is thinking of, write a list or draw a picture, etc. Active language use is realized through volume and repetition of the given structure (Ur 1995: 17-18). By the term volume Penny Ur cosiders "the sheer amount of (comprehensible) language that is spoken, heard, read or written in the course of the activity" (Ur 1995: 12). The second component intrinsic interest generates motivation. Apart

\footnotetext{
${ }^{6}$ These two types of drills are called imitation drills.
} 
from various factors that contribute to this kind of motivation, four elements will be singled out: variety of topics, visual focus, personalization and playacting. The first element offers a good choice of subject matter insuchaway that every student can come across what he or she is fascinated with. Any kind of sense cues, the most important visual cue, not only contribute to raising and maintainig children's attention but they also increase learners' comprehension and performance (Ur 1995: 19-22). Personalization which denotes sharing individual experiences, opinions, ideas and feelings by students plays an important role in holding full students' attention and creating a friendly and welcoming atmosphere. Play-acting which involves role-play ${ }^{7}$ and simulation ${ }^{8}$ give students an opportunity to use an ample scope of languge that would not find its way in the classroom (Ur 1995: 22-25). Last but not the least element of efficient activity is learner activation which involves learners' participation in the class. When students take part in the any exercise, they are more motivated and able to learn (Ur 1995: 25).

As for most activities done in these lessons in the primary schools, they tend to concetrate on the form rather than on the use of the new language. Such exercises are not only monotonous to both teachers and students but also have little or no learning value whatsoever.

\section{Discussion}

Comparing three classes, the most successful is the one about describing the location for a number of reasons. The context is provided by a large image of a house spread over the whole page in the book. The students practised new language through drills and were exposed to the comprehensible input. Pupils were engaged in drawing their own houses. Their language is personalized since the teacher asked them questions about the topic and they could give correct answers orally. However, all the teachers heavily rely on the deductive approach and translation. Students are spoon-fed and passive because teachers tell grammar rules instead of letting pupils to discover and formulate the rules by themselves. It seems as if students are learning English for the sake of grammar and grammar is seen as of utmost importance instead of communicating in English. The goal of learning any language is to enable the learner to use the language correctly and fluently both orally and in the written form. For this reason, grammar games need to be introduced because they consist of both linguistic and, more important, communicative goals. The learning cannot take place since they are not actively involved in the activity. The last two lessons are devoid of context and drills. In addition, teachers more test children through form-based exercises than they teach children. As a result, students make mistakes or fail to understand the lesson. In the presentation stage of likes and dislikes, the teacher could have made hand gestures and grimaces to show what food

\footnotetext{
${ }^{7}$ In a role-play, "each student takes on a particular personality for an individual purpose".(Ur $1995: 24)$

${ }^{8}$ In a simulation, "the entire group is talkinh through an imaginary situation as a social unit". (Ur 1995: 24)
} 
he or she likes or dislikes. In teaching uncountable and countable nouns the teacher might have brought realia to the class, i. e. real food products or flashcards.

Such way of teaching can be partially explained due to several reasons. Teachers working in public schools face numerous problems. On the one hand, the classrooms are ill-equipped and lack cutting-edge teaching materials. On the other, teacher are not well-trained or shy away from using computer technology. They have to adhere to the written school syllabus and do not have enough time to practise with their students. They need to maintain discipline over overcrowded and mixed-ability classes whereas group activities carry a certain risk because the teacher can lose control over the class easily. Children may consider game-like activities as unserious and therefore belittle their importance.

Over the past 20-30 years the image of a teacher has changed drastically after the political and economic turmoil in the former Yugoslavia. The role of a teacher has been undermined and the image tarnished. The media has also contributed to the bad reputation of a teacher depicting them as lazy. The Prime Minister of the day has told incorrect statements officially saying that teachers are entitled to more days off than they really have. The low salary has been cut by 10 percent due to austerity measures and therefore teachers are somewhat demotivated. The introduction of private universities and politicians with their diplomas testify that it is easy to get one in no time if you just pay for it. The image of education is underrated.

\section{Conclusion}

Language learning theories can be applied in practice in language teaching and learning in the classroom setting. Being immersed in the proper context (format), learners gain new knowledge and experience by taking actions (learning by doing) and accommodating to the new conditions in the environment. With the support of their parents and teachers, children can deal with challenges and problems successfully and therefore grow and develop through learning that motivates them and strikes an emotional chord with them. Through repetition and drills as scaffolding and applying old knowledge, a child feels comfortable, ready and confident to continue learning new things and the language itself. New learning is triggered by novelty.

The paper has explored the link between the age of children and the grammar. The aim of this paper is to see how grammar is presented, explained and practised with the students from the first to the fourth grade of primary schools in Belgrade, Serbia. By describing and observing classes, some conclusions have been reached. Teachers usually adhere to the deductive approach i. e. present grammar rules in Serbian and then practise with students. The research was conducted in two primary schools. Teachers deny the presence of grammar in the coursebooks for the 1st and 2nd grade because there is sometimes not a strict border between vocabulary and grammar, which they fail to recognize. Teachers do not usually carry out drills (only in the 2nd grade) when new language is introduced. Instead, they heavily rely on the translation, form-focused exercises and the grammatical paradigms. As a result, pupils are passive and 
spoon-fed. To improve both learning and teaching, teachers can permit students to discover the rules on their own. Harmer's general model for introducing new language can be applied in the classroom because the model provides a good context for meaning and use of new language which lessons lack. Moreover, grammar games need to be introduced because they draw student's attention, engage and motivate them in the very task which gives them an opportunity to activate new language talking about their own interests meaningfully and within the proper context. However, grammar-translation method in public primary schools can be explained due to a number of reasons. Teachers first need to maintain discipline in the mixed ability classes and then teach. The classroom are in dire need of new teaching materials. The class consists of over 25 students. The syllabus is comprehensive and too wide and there are not enough classes for practice. Since in our culture the learning is mostly perceived as serious and difficult, game-like activities might be considered easy and unimportant. Moreover, in our country, due to some economic and political changes, the image of a teacher has been tarnished drastically. In addition, the media and the government has characterised teachers in bad light whereas education is perceived as a commodity nor as an endeavouring process. The low salary has been decreased by 10 percent and education is seen as cost not as investment in the future.

\section{References}

1. Batstone, R. (1995). Grammar. Oxford: Oxford University Press

2. Cameron, L. (2005). Teaching Languages to Young Learners. Cambridge: Cambridge University Press

3. Gardner, H. (1993). Frames of Mind. The Theory on Multiple intelligences. New York: BasicBooks

4. Harmer, J. (1996). The Practice of English Language Teaching. London: Longman

5. Harmer, J. (1993). Teaching and Learning Grammar. London: Longman

6. Harmer, J. (2007). How to Teach English. Edinburgh Gate: Pearson Longman

7. Maidment, S. and L. Roberts (2010). Happy House 1. Oxford: Oxford University Press

8. Maidment, S. and L. Roberts (2010). Happy House 2. Oxford: Oxford University Press

9. Ur, P. (1995). Grammar Practice Activities. A practical guide for teachers. Cambridge: Cambridge University Press

10.Perrett, J. (2008). Brilliant 1. Pupil's Book. Oxford: Macmillian Education

11.Scrivener, J. (1994). Learning Teaching. A guidebook for English language teachers. London: Macmillan

12. Thornbury, S. (1999). How To Teach Grammar. Harlow: Pearson Education Limited

13. Ur, P. (1988). Grammar Practice Activities. A practical guide for teachers. Cambridge: Cambridge University Press

14. Vigotski, L. S. (1983). Mišljenje i govor. Beograd: Nolit

15.Žiropađa, Lj. and Lj. Miočinović (2007). Razvojna psihologija. Beograd: Čigoja štampa 


\section{УЗРАСТ УЧЕНИКА И ГРАМАТИКА У НАСТАВИ ЕНГЛЕСКОГ ЈЕЗИКА У НИЖИМ РАЗРЕДИМА ОСНОВНЕ ШКОЛЕ}

Сажетак: Циљ овог рада је да се пронађе начин на који се предаје, објашњава и увежбава граматика са ученичима узраста од првог до четвртог разреда у државним основним школама у Београду. Теорије Пијажеа, Виготског и Брунера о усвајању језика су кључне у објашњавању процеса учења и могу се применити у настави страних језика и предавању страних језика. Рад се такође бави поређењем теорије и школске праксе. Када су у питаюу методика и практични теренски рад, ауторка је одабрала дескриптивни пристип и посматрала је часове у вези са граматиком. Наставници углавном сматрају да не постоји граматика у првом и другом разреду и стога описи тих часова нису укључени у рад. Наставници су склони да објашњавају граматику почев од самих правила на матерњем језику и да преводе граматичке јединице односно примењују дедуктивни приступ. Упознавање деце са новом граматичком партијом лишено је контекста а самим тим и значења и посматра се одвојено док је једини начин да се објасни значење преко превода. Прочес учења и предавања су у потпуној супротности са теоријом. Како би се унапредила оба прочеса, модели који уводе нову јединииу могу се применити у учионици јер пружају контекст заједно са значење и употребом дате јединице. Наставници могу да активирају ученике навођењем питањима да би сами срочили граматичка правила. Међутим, наставнищи се суочавају са бројним проблемима у школи и у друштву који доводе у питање улогу наставника и само образовање: велики број ученика у одељењу, недостатак наставних средстава, преобиман наставни план и програм, мало часова за вежбу, одржавағе дисииплине, пољуљан углед наставника, ниска плата и образовање које се вреднује као роба.

Кључне речи: државне основне иколе, узраст, граматика, теорије о усвајању језика, предавање језика, учење језика, описи часова, дедуктивни приступ.

Примљено: 6. 4. 2018. године.

Одобрено за штампу: 14. 5. 2018. године. 